is 45.4 per cent higher than that recorded for 1934 , which was previously the largest total. "The increase in tonnage and in value is due largely to the extraordinary rise in the production of iron ore, which has been the predominant contributor to the total during recent years." This is scarcely surprising since the value of the iron ore raised in 1934 is 84 per cent of the total value of mineral production, the output showing an increase of 50 per cent; most other minerals showed increases, the output of gold being $6 \cdot 7$ per cent greater than that of 1934 . These statements are fairly well borne out by the reports of the Chief Inspector of Mines and the reports of the Inspector of Mines and Quarries attached as usual to this volume.

\section{Scientific Study of Suicide}

A commitres for the study of suicide consisting of ten members including Dr. Henry E. Sigerist, professor of the history of medicine at Johns Hopkins University, and Dr. Edward Sapir, professor of anthropology at Yale University, has recently been incorporated to make a comprehensive study of suicide as a social and psychological phenomenon. The following general outline has been adopted by the Committee : (1) intramural studies of individuals inclined to suicide in selected hospitals for mental diseases ; (2) extramural studies of ambulatory cases with suicidal trends or with obsessional wishes for their own death; (3) social studies of suicide; (4) ethnological studies, that is, comprehensive investigation of suicide among primitive races ; (5) historical studies.

\section{Ministry of Agriculture Leaflets}

Four advisory leaflets have recently been rewritten for the Ministry of Agriculture and Fisheries. No. 267, which replaces the former Leaflet No. 296, deals with "Potato Growing in Allotments and Gardens". The section on autumn preparation of soil directs attention to the importance of taking precautions against wireworms and leather jackets. It is not now recommended that seed be saved from a previous crop grown in the same district, owing to the depredations of virus disease, and the account of manuring is also brought into line with modern research. Advisory Leaflets No. 180, on "The Cultivation of Raspberries", and No. 268, on "Plums and Damsons", are revised mainly in the sections dealing with soils, diseases and manuring. The fourth Leaflet, No. 113, portrays, briefly, but with businesslike adequacy, modern methods of chicken rearing. The descriptions of sanitary considerations reflect modern research findings upon avian disease, the merits of the various systems of hovers and battery brooders are discussed, and the very considerable advances recently made in our knowledge of the food requirements of poultry are very evident in the section on feeding.

\section{World Power Conference}

IN accordance with the constitution of the World Power Conference, which states that the country in which a plenary meeting is held shall appoint the president, Mr. William F. Durand, chairman of the Third World Power Conference, has been appointed to serve until the next plenary meeting. Sir Harold Hartley has been re-elected chairman of the International Executive Council to hold office until the next plenary meeting, and the following have been elected vice-chairmen, to hold office for three years : First Vice-Chairman: Mr. O. C. Merrill (U.S.A.), director of the Third World Power Conference; Second Vice-Chairman : Mr. G. J. T. Bakker, president of the Royal Netherlands Institute of Engineers; Third Vice-Chairman: Dr. M. Kamo, professor in the Faculty of Engineering, Tokyo Imperial University. The Second Chemical Engineer ing Congress will be held in Berlin in 1940, by invita tion of the German National Committee.

\section{Books on Zoology}

SeVEral catalogues of books and periodicals dealing with aspects of biological science have recently appeared. Bernard Quaritch's general catalogue (No. 521) lists all classes of zoological works, to the number of 965 . The most complete section is that dealing with entomology, in which is included a selection of books from the library of the late Robert Adkin. Another of Quaritch's catalogues (No. 524) contains two sections of books on early medicine and surgery, and on early science, in all 83 volumes, most of them belonging to the sixteenth, seventeenth and early eighteenth centuries. Messrs. Wheldon and Wesley's catalogue of books on ornithology (N.S. No. 43) is a useful bibliography of birds, listing 1,289 items, the majority of which are arranged geographically.

\section{The Night Sky in October}

Between October 1 and 31 , the days shorten by $1^{\mathrm{h}} 48^{\mathrm{m}}$ in the southernmost part of the British Isles and by $2^{\mathrm{h}} 47^{\mathrm{m}}$ in the northernmost part. British Summer Time ends on Oct. $4^{\mathrm{d}} 2^{\mathrm{h}}$ U.T. The moon is new on Oct. $15^{\mathrm{d}} 10 \cdot 3^{\mathrm{h}}$, and full (the Hunter's Moon) on Oct. $30^{d} 6 \cdot 0^{\mathrm{h}}$. Of the lunar occultations visible from Greenwich, the following may be noted: $v$ Tauri (mag. 4.4 ) on Oct. $4^{\mathrm{d}} 20^{\mathrm{h}} 43 \cdot 7^{\mathrm{m}}$ as a re. appearance : $\tau$ Tauri (mag. $4 \cdot 3$ ) on Oct. $5^{\text {d }} 3^{\text {h }} 2 \cdot 8^{\mathrm{m}}$ as a disappearance and its subsequent re-appearance at $3^{\mathrm{h}} 44^{\mathrm{m}}$ : A Tauri (mag. $4 \cdot 5$ ) on Oct. $31^{\mathrm{d}} 21^{\mathrm{h}} 56 \cdot 9^{\mathrm{m}}$ as a disappearance and at $22^{\mathrm{h}} 55 \cdot 7^{\mathrm{m}}$ as a reappearance of the star. The planets visible during October are as follows: Mercury as a morning star at greatest west elongation on October 16 : Venus as an evening star in gibbous phase; Jupiter as an evening star. Saturn is visible throughout the night; its ring system appears nearly closed, the minor axis being about $2^{\prime \prime}$. The apparent paths of Uranus (stellar magnitude at opposition $6 \cdot 0$ ) and Neptune (mag. $7 \cdot 7$ ) are given in graphical form in the "Handbook" of the British Astronomical Association for 1936 . On October 31, Uranus is in opposition, when its distance from the earth will be about 1,745 millions of miles. Mars is in conjunction with Neptune on October 25, when the former planet will be only 
$0.4^{\circ}$ north of the latter. The light variations of Algol (R.A. $3^{\text {h }} 4^{\mathrm{m}}$ : Dec. $40^{\circ} 43^{\prime}$ N.) may be observed at about the following times, which represent approximately the mid-epoch of diminished light: Oct. $1^{\mathrm{d}} 19^{\mathrm{h}}, 16^{\mathrm{d}} 3^{\mathrm{h}}, 19^{\mathrm{d}} 0^{\mathrm{h}}, 21^{\mathrm{d}} 21^{\mathrm{h}}$ and $24^{\mathrm{d}} 18^{\mathrm{h}}$. A nova of the 8th magnitude at discovery on September 18 has been reported from Copenhagen, the discoverer being Mr. N. Tamm of Kvistaberg, Sweden. Its position in Aquila is R.A. $19^{\mathrm{h}} 13^{\mathrm{m}} 59 \cdot 5^{\mathrm{g}}:$ Dec. $1^{\circ} 36^{\prime} 31^{\prime \prime} \mathrm{N}$., not far from the 4th magnitude star, $\delta$ Aquilæ. The nova is fading, and on Sept. $23 \cdot 8^{d}$ was reported by Steavenson as being of magnitude 8.8. The comet discovered on September 20 by $\mathrm{Mr}$. C. Jackson at the Union Observatory, Johannesburg, is in Aquarius, but it is very faint, and invisible except to large telescopes.

\section{Announcements}

Ir is announced in The Times that Convocation of the University of Cape Town has elected General Smuts as Chancellor of the University in succession to the King, who held that office while Prince of Wales but vacated it on his accession.

THE Ramsay Memorial Fellowship Trustees have made the following awards of new fellowships for the year 1936-37: Dr. E. D. Hughes, a British fellowship of $£ 300$, tenable for two years, Mr. R. R. Gordon, a Glasgow fellowship of $£ 300$, tenable for two years, and Dr. D. Porret, a Swiss fellowship of $£ 300$, all at University College, London. The Trustees have renewed the following fellowships for a second year: Dr. N. Ando (Japanese fellow), University College, London; Mr. C. S. Lees (British fellow), University of Cambridge; Dr. D. MacGillavry (Netherland fellow), University of Cambridge.

AT a recent meeting the Association of German Röntgenologists and Radiologists in Czechoslovakia decided to found a Jaksch Prize on the occasion of the eightieth birthday of its president, Prof. Rudolf Jaksch Wartenhorst, to be awarded annually to young röntgenologists who have distinguished themselves by good scientific work.

THE fourth European Congress of Mental Hygiene will be held at the Conference Hall, Ministry of Health, on October $5-8$, when the following subjects will be discussed : mental hygiene and the cinema; mental hygiene and the nurse; and mental hygiene and the child from eleven to eighteen years. A reception will be given by the Government at Lancaster House on October 5 or 6 , and visits will be paid on October 7 and 8 to various psychiatric hospitals, clinics and colonies. The official languages of the Congress will be English, French and German. Further information can be obtained from the Secretary, National Council for Mental Hygiene, Chandos House, Palmer Street, London, S.W.1.

Is view of the many requests that have been received from those who attended the conference on mechanization in agriculture held in Oxford last January, it has been decided to hold a second conference at Rhodes House, Oxford, on January
5-8, 1937. A detailed programme will be sent in due course on application to the Conference Secretary, Institute for Research in Agricultural Engineering, Parks Road, Oxford.

OWING to the present condition of affairs in Spain, the third International Congress of Malaria, which was to have been held at Madrid on October 12, has been postponed, but it is hoped that it will take place in the spring or summer of 1937.

The sixth Italian Congress of Microbiology will be held at Milan in April 1937. Further information ean be obtained from the secretariat, Via Darwin 20, Milan, 124.

Messrs. Francis Edwards, Lto., have issued a useful catalogue on Africana (No. 602), which contains a long classified list including several scarce volumes and also a number of autograph letters of David Livingstone referring to his African work.

Applications are invited for the following appointments, on or before the dates mentioned :

A civil engineer and a mechanical engineer in the War Department--Under-Secretary of State (C. 5), War Office, S.W.1, quoting "O.P." (October 7).

A lecturer in metal mining in the University of Birmingham-The Secretary (October 9).

A lecturer in electrical engineering at the County Technical College, Worksop-The Principal (October 10).

A male assistant (Grade II) for radio work in a Government establishment in the south of EnglandSecretary, Royal Engineer and Signals Board, Regent's Park Barracks, Albany Street, London, N.W.1 (October 17).

Temporary assistants (Grade III) at the Royal Aircraft Establishment, South Farnborough, Hants, for ballistic calculations - Chief Superintendent, quoting "No. A.233"' (October 12).

A professor in ship design and shipbuilding at the Royal Technical College, Copenhagen-The King, Ministry of Education, Copenhagen, K (October 22).

A regius professor of pathology in the University of Aberdeen-Private Secretary, Scottish Office, Whitehall, S.W.1 (October 31).

A skilled scientific instrument maker at University College, Exeter-The Registrar.

Temporary heating assistants in the drawing office of the Works and Buildings Directorate, Air Ministry -The Secretary (W.B. 9), Air Ministry, Adastral House, Kingsway, W.C.2, by postcard.

Temporary assistants in the drawing office, Civil Engineer-in-Chief's Department, Admiralty-Civil Engineer-in-Chief, Admiralty, S.W.1, marked "Temporary Eng. Assts."

Unestablished assistants in the drawing offices at the Admiralty and H.M. Dockyards-Civil Engineerin-Chief, Admiralty, S.W.1, marked "Grade III".

An examiner in the Aeronautical Inspection Directorate (A.I.D.) Test House, Cardington, Beds. (metallic materials section, micrographic subsection) - Secretary (S.2.d.), Air Ministry, Adastral House, Kingsway, W.C.2. 